\title{
Article \\ Effect of Pretreatment with Low-Frequency Ultrasound on Quality Parameters in Gulupa (Passiflora edulis Sims) Pulp
}

\author{
Vanessa Calderón-Martínez ${ }^{1}$, Johannes Delgado-Ospina ${ }^{2,3, * \mathbb{D}}$, Juan Sebastián Ramírez-Navas ${ }^{4,5}$, (D), \\ Edwin Flórez-López ${ }^{1}$ D , Magda Piedad Valdés-Restrepo ${ }^{6}$, Carlos David Grande-Tovar ${ }^{7, *(\mathbb{D})}$ and \\ Clemencia Chaves-López ${ }^{3}$ iD
}

1 Grupo de Investigación en Química y Biotecnología (QUIBIO), Universidad Santiago de Cali, Calle 5 \# 62-00, Cali 760035, Colombia; vanessa.calderon00@usc.edu.co (V.C.-M.); edwin.florez00@usc.edu.co (E.F.-L.)

2 Grupo de Investigación Biotecnología, Facultad de Ingeniería, Universidad de San Buenaventura Cali, Carrera 122 \# 6-65, Cali 760032, Colombia

3 Faculty of Bioscience and Technology for Food, Agriculture and Environment, University of Teramo, Via R. Balzarini 1, 64100 Teramo, Italy; cchaveslopez@unite.it

4 Grupo de Investigación en Procesos Agroalimentarios y Biotecnológicos (GIPAB), Escuela de Ingeniería de Alimentos, Universidad del Valle, Cali 760032, Colombia; juan.sebastian.ramirez@correounivalle.edu.co

5 Food and Nutrition Department, Faculty of Health Science, Pontificia Universidad Javeriana Cali, CL 18 No 118-250, A.A. 26239, C.P., Cali 760031, Colombia

6 Research Group Biotics, Faculty of Basic Sciences, Technology and Engineering, Universidad Nacional Abierta y a Distancia, Palmira 763531, Colombia; magda.valdes@unad.edu.co

7 Grupo de Investigación de Fotoquímica y Fotobiología, Universidad del Atlántico, Carrera 30 \# 8-49, Puerto Colombia 081008, Colombia

check for updates

Citation: Calderón-Martínez, V.; Delgado-Ospina, J.; Ramírez-Navas, J.S.; Flórez-López, E.; Valdés-Restrepo, M.P.; Grande-Tovar, C.D.; ChavesLópez, C. Effect of Pretreatment with Low-Frequency Ultrasound on Quality Parameters in Gulupa (Passiflora edulis Sims) Pulp. Appl. Sci. 2021, 11, 1734. https://doi.org/ 10.3390/app11041734

Academic Editor: Dong-Un Lee Received: 26 January 2021

Accepted: 9 February 2021

Published: 16 February 2021

Publisher's Note: MDPI stays neutral with regard to jurisdictional claims in published maps and institutional affiliations.

Copyright: (c) 2021 by the authors. Licensee MDPI, Basel, Switzerland. This article is an open access article distributed under the terms and conditions of the Creative Commons Attribution (CC BY) license (https:/ / creativecommons.org/licenses/by/ $4.0 /)$.
* Correspondence: jdelgado1@usbcali.edu.co or jdelgadoospina@unite.it (J.D.-O.); carlosgrande@mail.uniatlantico.edu.co (C.D.G.-T.)

Featured Application: Ultrasound treatment offers a new strategy to improve and extend the shelf life in minimally processed fresh fruit.

Abstract: The Gulupa (Passiflora edulis f. edulis Sims) is an expression of South America's tropics' biodiversity, and a source of B vitamins and amino acids. It is a climacteric export fruit for which it is necessary to incorporate emerging technologies for its conservation and transport. This work investigated the effect of ultrasound on gulupa pulp and verified the stability of the characters of interest in the shelf life of 20 days. Six treatments and a control sample were used, evaluated in triplicate, and varied in frequency ( 30 and $40 \mathrm{kHz}$ ) with an exposure time of 10, 20, and $30 \mathrm{~min}$. A statistical analysis of unidirectional variances and Dunnett's test was used. It was found that the ultrasound treatments did not affect the $\mathrm{pH}$ or the titratable acidity. Soluble solid results presented a significant increase $(p<0.05$ ) (from 13.4 to $14.8 \% w / v)$ in the antioxidant capacity (from 1.13 to $1.54 \mu \mathrm{mol}$ Trolox Equivalent (TE)/g by the ABTS $\bullet+\left(2,2^{\prime}\right.$-azino-bis(3-ethylbenzothiazoline-6-sulfonic acid)) Cationic Radical Assay and from 3.3 to $3.7 \mu \mathrm{mol} \mathrm{TE} / \mathrm{g}$ by the DPPH. (2,2-diphenyl-1-picrilhydrazil) Radical Scavenging Assay). During the shelf life, ascorbic acid was the parameter that varied most $(p<0.05)$. It decreased from 42.7 to $21.6 \mathrm{mg}$ ascorbic acid/100 $\mathrm{g}$ of pulp in the control sample. However, a smaller decrease was observed (23.8-24.5 mg ascorbic acid/100 g of pulp) in the $40 \mathrm{kHz}$ treatments. The smallest global color difference $(\Delta \mathrm{E})$ for the control was found in the $40 \mathrm{kHz}$ treatment at $30 \mathrm{~min}$ through the entire shelf life (day 0 to 20). Ultrasound treatment offers a new strategy to improve and extend the shelf life of chilled gulupa pulp.

Keywords: antioxidant capacity; biomolecules; conservation; postharvest; pulp; shelf life

\section{Introduction}

Gulupa (P. edulis f. edulis), also known as purple passion fruit, of the Passifloraceae family, is a climbing plant native to southern Brazil, Paraguay, and northern Argentina. It 
is produced mainly in Brazil, followed by Venezuela, Colombia, and the rest of the tropical countries [1], from where it is mainly exported to the European Union. Colombia has the most remarkable diversity of the genus Passiflora, among which P. edulis f. flavicarpa (yellow passion fruit), P. edulis f. edulis (purple passion fruit or gulupa), P. ligularis (sweet granadilla or grenadia), and P. mollissima (banana passion fruit or curuba) are the most desired in international markets. In 2019, Colombia exported 8725 tons of Gulupa, representing 2.9\% of the world market [2].

The gulupa fruit selected for export is harvested in an intermediate ripening stage ( 3 or 4 ) on the scale proposed by Pinzón et al. [3]. Maximum pulp yields are reached in this state, representing between 35 and $50 \%$ of the total weight. Gulupa is an excellent source of ascorbic acid, thiamine, riboflavin, niacin, calcium, and phosphorus. Its pulp is used to prepare juices and soft drinks. It has essential nutrients with antioxidant properties, such as vitamins, polyphenolic compounds, carotenoids, anthocyanins (cyanidin-3-O- $\beta$-Dglucopyranoside), and amino acids that make it attractive for consumption $[4,5]$.

As it is a climacteric fruit, during the postharvest, transport, storage, and marketing period, it continues its normal ripening process, which can cause it to reach maturity before reaching the final consumer, losing its organoleptic quality and causing economic losses for exporting companies of up to $15 \%$ of the total volume shipped [5]. Therefore, the transformation of gulupa into the pulp as a minimally processed product represents for producers the opportunity to add value to their product and at the same time reduce exportation over costs by transporting less than half the volume, a process that would allow them to control adequately the quality of the product, preserving its nutritional characteristics and obeying changes in consumer preferences. Emerging technologies for food preservation and transformation seem to be the best alternative to achieve the mentioned characteristics. This evolution forces food industries to adapt to new production techniques and current market demands, integrating social and natural sciences, engineering, and technology [6]. These technologies, including high pressure, electrical pulses, and ultrasound, are specially designed for economy, simplicity, and energy efficiency [7].

Generally, ultrasound (US) is used and referred to as high- and low-energy applications. When the frequency is between 20 and $100 \mathrm{kHz}$, it is known as high-energy ultrasound (greater than $1 \mathrm{Wcm}^{-2}$ ) or low frequency. When the frequency is more significant than $100 \mathrm{kHz}$, the energy supplied is less than $1 \mathrm{Wcm}^{-2}$. High doses of energy provided to the sample can have the desired effects with the application of ultrasound, but at the same time, it can generate adverse effects such as the degradation of some compounds of interest. The previous statement is why the best effects must be found with the least amount of energy applied.

Low-power and high-frequency ultrasound (US) are used to analyze, control, and process, ensuring safe and high-quality food. Its technology uses acoustic energy, nonionizing mechanical energy, and is noninvasive and nonpolluting [8]. This innovative nonthermal technique inactivates microorganisms and enzymes related to degradation in fruits, thus allowing the retention of quality nutrients in fruits and their derivatives. The US's biocidal effect has been attributed mainly to physical principles (cavitation, mechanical effects, micromechanical shocks) and chemicals with the formation of free radicals due to the sonochemical reaction [9]. The technique is considered low-energy, environmentally friendly, and reduces chemical and physical risks, with minimal processing time. The technique is considered low-energy, environmentally friendly, reduces chemical and physical risks, and has minimal processing time [10,11].

US technology is useful in enhancing the rate of food processing techniques such as cutting, filtration, freezing, extraction, pickling, and drying [12,13]. The US's mechanical effect facilitates dehydration through the drying process [14]. Moreover, US improves the freezing process by increasing ice crystals formation before the freeze-drying (FD) $[15,16]$. Besides, US is a food dehydration method itself, avoiding the decomposition of food due to a low heat application [17] based on the moderate temperatures generated [18]. 
The effect of ultrasound (US) pretreatment on freeze-dried quince slices was reported by Yildiz and Izli [19]. They showed higher preservation of bioactive compounds and improved physical properties compared to the untreated fruit samples.

Rodriguez et al. [20] demonstrated that ultrasound pretreatment significantly increased the dehydration rate and solid gain of Sanhua plum during osmotic dehydration without affecting the fruits. Žlabur et al. [21] found that the US pretreatment of honeyberry fruits increased the vitamin $C$ content regardless of the drying technology used.

During atmospheric FD of apples, carrots, and eggplants, US application demonstrated a decrease in the drying time and improved the FD process. Colucci et al. [22] demonstrated that the US caused no destructive effect on eggplants' antioxidant potential or quality aspects. The US pretreatment of onions before FD increased the flavonoids, quercetin, and phenolic content up to $20 \%$. It improved the antioxidant activity of dried vegetables, only if the US treatment was for short periods, but prolonged sonication harmed the antioxidant activity and antioxidant content compounds [23].

There is evidence of the benefits of ultrasound treatment in the dairy industry, fruits, and processed juices. However, it has been found that it can behave differently in various food matrices, especially concerning the stability of its biomolecules such as ascorbic acid [24]. Therefore, it is necessary to know the low-frequency ultrasound effect on the gulupa pulp as neither the thermal processing nor the sonication effects on the quality parameters of the gulupa have been reported to date.

\section{Materials and Methods}

\subsection{Vegetal Material}

Gulupa fruits (Passiflora edulis f. edulis) were selected in a state of maturation three [3], from a crop certified for export by the Colombian Institute of Agriculture (ICA), located in the municipality of Pradera (Valle del Cauca, Colombia) at 2430 m.a.s.l. and coordinates $3^{\circ} 25^{\prime} 39.6^{\prime \prime} \mathrm{N} 76^{\circ} 05^{\prime} 54.6^{\prime \prime} \mathrm{W}$.

The gulupa fruits were selected according to the appearance of quality and physical characteristics (homogeneous color, size, without bruises and wrinkles). The fruits were washed with a mixture of $70 \%$ ethyl alcohol and $5 \%$ sodium hypochlorite. The fruits were cut in half to obtain the pulp, and the pulp, including the seeds, was extracted with a sterile spoon according to the procedure described by the Colombian technical standard (NTC 5468:2012) [25], and $100 \mathrm{~g}$ of pulp was placed in sterile zip-lock polyethylene bags of size $4 \times 5.6$ inch $(10.16 \times 14.224 \mathrm{~cm})$ (Ziploc, Sc Johnson, Racine, WI, USA); each of them was considered an experimental unit.

\subsection{Treatments}

The low-frequency ultrasound treatments consisted of applying an ultrasound power of 325 W (UCD-150 Raypa Leading Lab Technologies, Terrassa, Barcelona, Spain) to the gulupa pulp, varying the frequency ( 30 and $40 \mathrm{kHz}$ ) and the exposure time $(10,20$, and 30 min), obtaining six (6) treatments and one (1) control sample. The treatments chosen in this work were based on the results from $[10,11,24,26]$, in which frequencies of $20 \mathrm{kHz}$ were used.

During the ultrasound treatment, agitation within the bag was not required, due to the dispersion effect caused by the technique; it induces a longitudinal displacement of particles [8], favored by the low viscosity of the pulp. During the ultrasound treatments, an ice bath was applied to maintain the gulupa pulp samples' temperature at $5{ }^{\circ} \mathrm{C}$. After performing the treatments, the samples were stored at $5^{\circ} \mathrm{C}$ until their use in the tests. All tests were carried out in triplicate every four days until 20 days were completed.

\subsection{Titratable Acidity and $p H$}

Titratable acidity was determined by standard procedure with a $0.1 \mathrm{~N}$ sodium hydroxide solution in phenolphthalein's presence as an indicator. The $\mathrm{pH}$ of the pulp was determined directly with an electrode probe connected to a potentiometer (model FE20 
Mettler Toledo, Columbus, OH, USA) according to the international standard (AOAC $981.12,1982)$ [27].

\subsection{Soluble Solids (SS)}

They were determined in a small pulp juice sample using an Atago refractometer (0-32 ATC Fukaya-shi, Saitama, Japan). The results were expressed in ${ }^{\circ}$ Brix.

\subsection{Trolox Equivalent Antioxidant Capacity (TEAC)}

\subsubsection{ABTS $^{\bullet+}\left(2,2^{\prime}\right.$-azino-bis(3-ethylbenzothiazoline-6-sulfonic acid) Cationic Radical}

The ability to trap free radicals was measured by the ABTS cation radical discoloration test, according to [28]. For this, $30 \mu \mathrm{L}$ of each sample conveniently diluted in phosphate buffer solution $\mathrm{pH} 7.4$ (PBS) was mixed with $2.97 \mathrm{~mL}$ of the ABTS $\left(2,2^{\prime}-\right.$ azino-bis(3-ethylbenzothiazoline-6-sulfonic acid)) solution prepared and standardized to $0.70 \pm 0.02$ absorbance units. The discoloration of ABTS ${ }^{\bullet+}$ in the sample's presence was monitored at $734 \mathrm{~nm}$ after six minutes of reaction using a Genesys 20 spectrophotometer (Thermo Scientific, Waltham, MA, USA). Antioxidant activity was determined as $\mu \mathrm{mol}$ of Trolox-equivalent per gram of pulp using the ratio of the correlation coefficient of the sample's dose-response curve and the dose-response curve of the standard.

\subsubsection{DPPH· (2,2-diphenyl-1-picrilhydrazil) Radical Scavenging Assay}

The activity of removing free radicals from the pulp was determined according to [29] with some modifications. The stock solution was prepared by dissolving $2.5 \mathrm{mg}$ of DPPH. (2,2-diphenyl-1-picrilhydrazil) in $100 \mathrm{~mL}$ of methanol and adjusting the solution to absorbance $0.70 \pm 0.02$ at $515 \mathrm{~nm}$. For free radical determinations, $100 \mu \mathrm{L}$ of diluted pulp was used and mixed with $2.9 \mathrm{~mL}$ of standardized DPPH. The mixture was vortexed (IKA, Staufen im Bresigau, Germany) and kept in the dark for $30 \mathrm{~min}$, and then the absorbance was read on a spectrophotometer. The results were expressed as $\mu$ mol Trolox-equivalent per gram of pulp. The analyses were carried out in triplicate.

\subsection{Determination of Ascorbic Acid}

Determination of the ascorbic acid content was carried out using a Thermo scientific ultimate 3000 HPLC liquid chromatography (Waltham, MA, USA), equipped with a UV/VIS detector at $245 \mathrm{~nm}$. The sample mixture preparation consisted of a $20 \mu \mathrm{L}$ aliquot of pulp diluted in $20 \mathrm{~mL}$ of distilled water using a dark bottle to protect it from light. Then, it was filtered through a $0.22 \mu \mathrm{m}$ PVDF filter, and $20 \mu \mathrm{L}$ was injected into a C-18 column $(2.7 \mu \mathrm{m}, 150 \mathrm{~mm} \times 2.1 \mathrm{~mm})$ at $30^{\circ} \mathrm{C}$ using a $5 \mathrm{mM}$ phosphate buffer solution at $\mathrm{pH} 2.5$ as a mobile phase and at a flow rate of $0.2 \mathrm{~mL} \mathrm{~min}^{-1}$. The peak was identified by comparing the ascorbic acid L-(+) standard's retention time, according to the external standard calibration curve for L-(+) ascorbic acid [30]. The results were expressed in $\mathrm{mg} / 100 \mathrm{~g}$ of pulp.

\subsection{Color Determination}

Colorimetric analysis of the pulp was determined using a CM-700d spectrophotometer (Konica Minolta, Osaka, Japan) with the following settings: Illuminant D65, observer $10^{\circ}$. The pulp was deposited in a black cylinder $3 \mathrm{~cm}$ deep. The CIELAB color coordinates ( $\mathrm{L}^{*}$, $\mathrm{a}^{*}$, and $\mathrm{b}^{*}$ ) and $\Delta \mathrm{E}^{*}$ were determined. The reported values correspond to the average of 5 measurements. The $\Delta \mathrm{E}^{*}$ parameter was calculated with the following equation:

$$
\Delta E^{*}=\sqrt{\left(\Delta L^{*}\right)^{2}+\left(\Delta a^{*}\right)^{2}+\left(\Delta b^{*}\right)^{2}}
$$

\subsection{Microbiological Analysis}

Following the method described by the Colombian technical standard (NTC 5468:2012) [25], $100 \mu \mathrm{L}$ of each of the dilutions of the treatments $\left(10^{-1}\right.$ to $10^{-6}$ in buffered peptone water, $0.1 \% w / v)$ was sown in the following culture media: For Enterobacteriaceae in Crystal Violet-Neutral Red-Bile-Glucose Agar (VRBD) for $48 \mathrm{~h}$ at $37^{\circ} \mathrm{C}$; for aerobic mesophylls in 
Plate Count Agar (PCA) for $24 \mathrm{~h}$ at $30^{\circ} \mathrm{C}$; for psychrophiles in PCA at $4{ }^{\circ} \mathrm{C}$ for $96 \mathrm{~h}$; for yeasts on Yeast Peptone Dextrose (YPD) at $30^{\circ} \mathrm{C}$ for $24 \mathrm{~h}$; and for filamentous fungi on potato dextrose agar (PDA) for $96 \mathrm{~h}$ at $25^{\circ} \mathrm{C}$.

\subsection{Statistic Analysis}

The results were analyzed using one-way analysis of variances (ANOVA) with Minitab 18 statistical software. The significant differences between means $(p<0.05)$ were determined with Dunnett's test. All data are presented as mean values \pm standard deviation. The extraction and treatments were performed in duplicate (one month separate), and the tests were performed in triplicate.

\section{Results and Discussions}

\subsection{Titrable Acidity and $p H$}

The effect of ultrasound on the gulupa pulp's $\mathrm{pH}$ did not show significant differences $(p>0.05)$ between the treatments during the 20 days of observation (average export and distribution). The values ranged from $2.72 \pm 0.01$ to $2.86 \pm 0.02$ (Table 1). Similar results were reported for juices with ultrasound treatment of Citrus microcarpa (Lima kasturi) and Malus domestica (Apple), where the changes in $\mathrm{pH}$ due to ultrasound treatment were meager, from 4.0 to 3.9 and from 2.68 to 2.66 , respectively [31,32]. The low $\mathrm{pH}$ values in the control and treatments that remain stable over time are mainly due to a self-regulating or buffering system involving citric acid [5,33] like that found in Passiflora edulis f. flavicarpa [34].

Table 1. Changes in $\mathrm{pH}$ during storage at $4{ }^{\circ} \mathrm{C}$ of Passiflora edulis f. edulis Sims (gulupa) pulp subjected to low-frequency ultrasound treatments.

\begin{tabular}{cccccccc}
\hline \multirow{2}{*}{ Power (kHz) } & \multirow{2}{*}{ Time (min) } & \multicolumn{5}{c}{ Days after Treatment } \\
\cline { 3 - 7 } & & $\mathbf{0}$ & $\mathbf{4}$ & $\mathbf{8}$ & $\mathbf{1 2}$ & $\mathbf{1 6}$ \\
\hline \multirow{2}{*}{ Control } & & $2.81 \pm 0.02$ & $2.80 \pm 0.11$ & $2.80 \pm 0.01$ & $2.76 \pm 0.01$ & $2.76 \pm 0.01$ & $2.77 \pm 0.03$ \\
& 10 & $2.72 \pm 0.01$ & $2.79 \pm 0.01$ & $2.75 \pm 0.02$ & $2.73 \pm 0.01$ & $2.78 \pm 0.02$ & $2.74 \pm 0.01$ \\
30 & 20 & $2.77 \pm 0.01$ & $2.80 \pm 0.03$ & $2.78 \pm 0.01$ & $2.76 \pm 0.01$ & $2.80 \pm 0.01$ & $2.81 \pm 0.02$ \\
& 30 & $2.86 \pm 0.02$ & $2.74 \pm 0.01$ & $2.80 \pm 0.01$ & $2.77 \pm 0.01$ & $2.78 \pm 0.01$ & $2.73 \pm 0.01$ \\
& 10 & $2.81 \pm 0.01$ & $2.76 \pm 0.01$ & $2.78 \pm 0.02$ & $2.74 \pm 0.01$ & $2.79 \pm 0.01$ & $2.75 \pm 0.02$ \\
40 & 20 & $2.76 \pm 0.02$ & $2.75 \pm 0.02$ & $2.76 \pm 0.01$ & $2.72 \pm 0.01$ & $2.77 \pm 0.01$ & $2.77 \pm 0.01$ \\
& 30 & $2.81 \pm 0.01$ & $2.74 \pm 0.01$ & $2.77 \pm 0.01$ & $2.78 \pm 0.01$ & $2.80 \pm 0.02$ & $2.78 \pm 0.01$ \\
\hline
\end{tabular}

Data expressed as mean \pm standard deviation of three repetitions. No statistically significant differences were found between the treatments.

In titratable acidity, there was a significant increase $(p<0.05)$ between day 0 and 4 for all treatments and the control (Table 2), due to the effect of obtaining the pulp, where the opening of the fruit begins to release some organic acids present at the level of the membranous sacs. After day four, small acidity changes were apparent, and at the end of the evaluation of the shelf life, the highest concentrations were presented in the control and the 30 min treatments. It is known that the accumulation of organic acids is the result of interactions between metabolism and vacuolar storage affected by environmental factors such as temperature and the opening of the fruit in this case [35]. As for other fruits, many factors affect the production of organic acids during the useful life of the gulupa pulp.

No differences were observed between the treatments' power (30 or $40 \mathrm{kHz})$, only in the exposure time. The 10 and 20 min treatments showed a significant decrease in acidity concerning the control (day 20), attributable to the deactivation of enzymes, which interrupts some metabolic processes involving organic acids, which is why the acidity could remain constant [36], observing a decrease concerning the control treatment. While the effect of ultrasound in treatments for $30 \mathrm{~min}$ was longer, it could favor the release of organic acids from the cell cytoplasm to the outside, caused by the rupture of the cell membrane when the enzymatic activity is decreased [37,38]. Therefore, in 30 min treatments, the effect increased acidity, matching the natural maturation effect that was carried out in the control treatment. 
Table 2. Titratable acidity (g citric acid/100 g of pulp) during storage at $4{ }^{\circ} \mathrm{C}$ of Passiflora edulis f. edulis Sims (gulupa) pulp subjected to low-frequency ultrasound treatments.

\begin{tabular}{cccccccc}
\hline \multirow{2}{*}{ Power (kHz) } & \multirow{2}{*}{ Time (min) } & \multicolumn{5}{c}{ Days after Treatment } \\
\cline { 3 - 7 } & & $\mathbf{0}$ & $\mathbf{4}$ & $\mathbf{8}$ & $\mathbf{1 2}$ & $\mathbf{1 6}$ & $\mathbf{2 0}$ \\
\hline \multirow{2}{*}{ Control } & & $4.4 \pm 0.2 \mathrm{aA}$ & $5.5 \pm 0.1 \mathrm{bC}$ & $5.6 \pm 0.2 \mathrm{bcC}$ & $5.5 \pm 0.2 \mathrm{bB}$ & $5.7 \pm 0.1 \mathrm{cB}$ & $5.9 \pm 0.1 \mathrm{~dB}$ \\
& 10 & $4.3 \pm 0.2 \mathrm{aA}$ & $5.0 \pm 0.2 \mathrm{bA}$ & $5.3 \pm 0.3 \mathrm{bB}$ & $5.4 \pm 0.1 \mathrm{bcB}$ & $5.4 \pm 0.1 \mathrm{bcA}$ & $5.5 \pm 0.1 \mathrm{cA}$ \\
30 & 20 & $4.3 \pm 0.2 \mathrm{aA}$ & $5.2 \pm 0.1 \mathrm{bA}$ & $5.4 \pm 0.4 \mathrm{bcBC}$ & $5.4 \pm 0.3 \mathrm{bcB}$ & $5.3 \pm 0.2 \mathrm{bA}$ & $5.6 \pm 0.1 \mathrm{cA}$ \\
& 30 & $4.2 \pm 0.2 \mathrm{aA}$ & $5.2 \pm 0.1 \mathrm{bA}$ & $5.3 \pm 0.2 \mathrm{bB}$ & $5.3 \pm 0.1 \mathrm{bA}$ & $5.5 \pm 0.2 \mathrm{bcA}$ & $5.8 \pm 0.3 \mathrm{cB}$ \\
& 10 & $4.2 \pm 0.3 \mathrm{aA}$ & $5.2 \pm 0.5 \mathrm{bAB}$ & $5.2 \pm 0.3 \mathrm{bA}$ & $5.1 \pm 0.4 \mathrm{bA}$ & $5.3 \pm 0.2 \mathrm{bcA}$ & $5.6 \pm 0.3 \mathrm{cA}$ \\
40 & 20 & $4.3 \pm 0.3 \mathrm{aA}$ & $5.3 \pm 0.8 \mathrm{bBC}$ & $5.0 \pm 0.5 \mathrm{bA}$ & $5.4 \pm 0.1 \mathrm{bB}$ & $5.4 \pm 0.1 \mathrm{bA}$ & $5.4 \pm 0.4 \mathrm{bA}$ \\
& 30 & $4.3 \pm 0.2 \mathrm{aA}$ & $5.2 \pm 0.1 \mathrm{bA}$ & $4.9 \pm 0.4 \mathrm{bA}$ & $5.3 \pm 0.2 \mathrm{bcA}$ & $5.4 \pm 0.2 \mathrm{cA}$ & $5.7 \pm 0.1 \mathrm{~dB}$ \\
\hline
\end{tabular}

Data expressed as mean \pm standard deviation of three repetitions. In the same row, different lowercase letters indicate statistically significant differences between treatment days $(p<0.05)$. In the same column, different capital letters indicate statistically significant differences between the treatments $(p<0.05)$.

\subsection{Soluble Solids (SS)}

The effect of ultrasound on the total solids of the gulupa pulp showed significant differences $(p<0.05)$ in the applied treatments (Table 3). Ultrasound at $30 \mathrm{kHz}$ for $30 \mathrm{~min}$ demonstrated an increase (from 13.4 to $14.8 \% w / v$ ), as well as those at $40 \mathrm{kHz}$ for 20 and $30 \mathrm{~min}$ (from 13.4 to 13.9 and $13.7 \% w / v$, respectively). These treatments may provide enough energy to break the high-molecular-weight chains of carbohydrates [39]. There was a decrease in soluble solids when ultrasound was applied at $40 \mathrm{kHz}$ for $10 \mathrm{~min}$ (from 13.4 to $12.7 \% w / v)$. At the end of the useful life evaluated, a decrease in soluble solids was only observed in the control and not between the treatments, which is consistent with studies carried out with apple juice (Malus domestica) [32], Carrot juice (Daucus carota L) [40], strawberry juice (Rubus ulmifolius) [41], pear juice (Pyrus communis) [42], and orange juice [43]. The decrease may be because ultrasound can cause enzyme deactivation and hinder the process of breaking down organic acids into sugars [36].

Table 3. Soluble solids $(\% w / v)$ during storage at $4{ }^{\circ} \mathrm{C}$ of Passiflora edulis f. edulis Sims (gulupa) pulp subjected to lowfrequency ultrasound treatments.

\begin{tabular}{cccccccc}
\hline \multirow{2}{*}{ Power (kHz) } & Time (min) & \multicolumn{5}{c}{ Days after Treatment } \\
\cline { 3 - 7 } & & $\mathbf{0}$ & $\mathbf{4}$ & $\mathbf{8}$ & $\mathbf{1 2}$ & $\mathbf{1 6}$ & $\mathbf{2 0}$ \\
\hline Control & & $13.4 \pm 0.2 \mathrm{bB}$ & $13.4 \pm 0.1 \mathrm{bB}$ & $13.4 \pm 0.1 \mathrm{bB}$ & $13.4 \pm 0.1 \mathrm{bB}$ & $13.1 \pm 0.1 \mathrm{aB}$ & $13.0 \pm 0.1 \mathrm{aA}$ \\
& 10 & $13.6 \pm 0.3 \mathrm{aB}$ & $13.5 \pm 0.2 \mathrm{aB}$ & $13.3 \pm 0.1 \mathrm{aB}$ & $13.3 \pm 0.1 \mathrm{aB}$ & $13.4 \pm 0.1 \mathrm{aB}$ & $13.3 \pm 0.1 \mathrm{aB}$ \\
30 & 20 & $13.5 \pm 0.2 \mathrm{aB}$ & $13.4 \pm 0.1 \mathrm{aB}$ & $13.3 \pm 0.1 \mathrm{aB}$ & $13.3 \pm 0.2 \mathrm{aB}$ & $13.4 \pm 0.1 \mathrm{aB}$ & $13.4 \pm 0.1 \mathrm{aB}$ \\
& 30 & $14.8 \pm 0.1 \mathrm{aD}$ & $14.8 \pm 0.1 \mathrm{aD}$ & $14.7 \pm 0.1 \mathrm{aD}$ & $14.7 \pm 0.1 \mathrm{aD}$ & $14.7 \pm 0.1 \mathrm{aD}$ & $14.7 \pm 0.1 \mathrm{aD}$ \\
& 10 & $12.7 \pm 0.1 \mathrm{aA}$ & $12.8 \pm 0.1 \mathrm{aA}$ & $12.9 \pm 0.2 \mathrm{aA}$ & $12.9 \pm 0.2 \mathrm{aA}$ & $12.8 \pm 0.1 \mathrm{aA}$ & $12.8 \pm 0.1 \mathrm{aA}$ \\
40 & 20 & $13.9 \pm 0.1 \mathrm{aC}$ & $13.8 \pm 0.1 \mathrm{aC}$ & $13.8 \pm 0.1 \mathrm{aC}$ & $13.8 \pm 0.0 \mathrm{aC}$ & $13.9 \pm 0.1 \mathrm{aC}$ & $13.9 \pm 0.1 \mathrm{aC}$ \\
& 30 & $13.7 \pm 0.1 \mathrm{aC}$ & $13.7 \pm 0.1 \mathrm{aC}$ & $13.8 \pm 0.1 \mathrm{aC}$ & $13.7 \pm 0.1 \mathrm{aC}$ & $13.7 \pm 0.1 \mathrm{aC}$ & $13.7 \pm 0.1 \mathrm{aC}$ \\
\hline
\end{tabular}

Data expressed as mean \pm standard deviation of three repetitions. In the same row, different lowercase letters indicate statistically significant differences between treatment days $(p<0.05)$. In the same column, different capital letters indicate statistically significant differences between the treatments $(p<0.05)$.

\subsection{Trolox-Equivalent Antioxidant Capacity (TEAC)}

In gulupa pulp, the values found in TEAC were $1.13 \pm 0.01 \mu \mathrm{mol} \mathrm{TE} / \mathrm{g}$ measured as ABTS, and $3.3 \pm 0.1 \mu \mathrm{mol} \mathrm{TE} / \mathrm{g}$ measured as DPPH (Figure 1). These results are close to those reported for gulupa with a state of more advanced maturation (ABTS 3.93 to $4.10 \mu \mathrm{mol}$ $\mathrm{TE} / \mathrm{g}$ ) [44]. In general, it was found that sonicated gulupa pulp has a great antioxidant capacity, like other Passifloras such as P. ligularis Juss (granadilla) and P. foetida (wild passion fruit) $[45,46]$. 

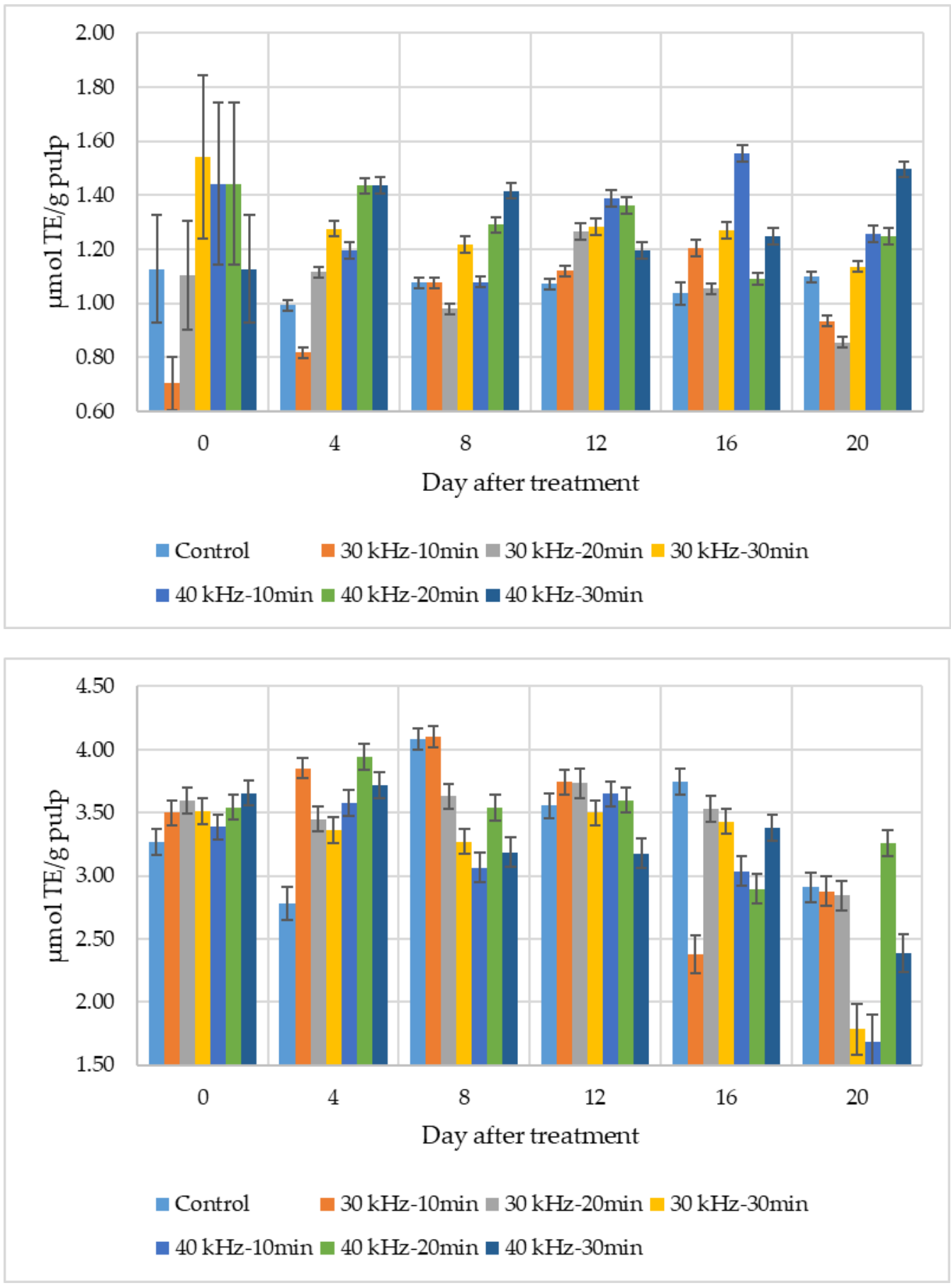

Figure 1. Changes in Trolox-Equivalent Antioxidant Capacity (TEAC) measured as ABTS ${ }^{\bullet+}\left(2,2^{\prime}-\right.$ azino-bis(3-ethylbenzothiazoline-6-sulfonic acid) Cationic Radical Assay (Top) and DPPH· (2,2diphenyl-1-picrilhydrazil) Radical Scavenging Assay (Bottom) during storage at $4{ }^{\circ} \mathrm{C}$ in Passiflora edulis f. edulis Sims pulp (gulupa) subjected to low-frequency ultrasound treatments. Data expressed as mean \pm standard deviation of three repetitions.

It was observed that ultrasound treatments showed a tendency to increase TEAC significantly (day 0) from $1.13 \pm 0.01$ to $1.54 \pm 0.01$ (ABTS) and from $3.3 \pm 0.1$ to $3.7 \pm 0.1$ (DPPH); only $30 \mathrm{kHz} 10 \mathrm{~min}$ treatment (measured as ABTS) presented a significant decrease in the control. In general, the increase in antioxidant capacity is possibly due to a more significant disruption of cell walls, facilitating the release of phenolic residues attached to traces of pectin, cellulose, hemicellulose, and lignin in the cell wall [47]. Similar results were reported in Fragaria $\times$ ananassa (strawberry) stored at $4{ }^{\circ} \mathrm{C}$ for 15 days, and Actinidia 
delicious (Kiwi) juice sonified with the US of $33 \mathrm{kHz}$ for $10 \mathrm{~min}$ and $20 \mathrm{kHz}$ for $16 \mathrm{~min}$, respectively [26]. In both investigations, a positive effect of this property was noted on the sonicated samples. This increase in antioxidant capacity with ultrasound treatment can also be attributed to the hydroxylation of flavonoids or the generation of hydroxyl radicals that increase the hydroxylation of food materials [36].

Storage did not show a marked tendency to increase or decrease the antioxidant activity significantly. There were highs and lows in each of the treatments; this property of the sonicated juice could be directly attributed to the US's cavitation, which could have caused the changes observed over the days [31].

It should be noted that ultrasound treatments do not tend to decrease antioxidant activity. Results are opposite to those identified in Passiflora caerulea, where it was found that in fresh and pasteurized juice, this property decreased from day 4 of storage [48]; additionally, refrigerated fresh fruit juices (for 29 days) have been reported to lose antioxidant potential [49].

According to the experimental conditions, it is considered that around 16 days of treatment is the most recommended time for the consumption of antioxidants, in agreement with Franco et al. 2014 [50]. On day 20, there was a decrease in TEAC measured as DPPH, possibly due to the decrease in some low-polarity antioxidant molecules, which react to a greater extent with this reagent.

\subsection{Ascorbic Acid Content}

An initial content of $42.7 \pm 0.2 \mathrm{mg}$ ascorbic acid/100 g of pulp was found, similar to those reported by Franco et al. [44] and Pertuzatti et al. [30] in organic crops in Brazil (Table 4).

Table 4. Ascorbic acid content (mg/100 g of pulp) during storage at $4{ }^{\circ} \mathrm{C}$ of the pulp of Passiflora edulis f. edulis Sims (gulupa) subjected to low-frequency ultrasound treatments.

\begin{tabular}{cccccccc}
\hline \multirow{2}{*}{ Power (kHz) } & Time (min) & \multicolumn{5}{c}{ Days after Treatment } \\
\cline { 3 - 7 } & & $\mathbf{0}$ & $\mathbf{4}$ & $\mathbf{8}$ & $\mathbf{1 2}$ & $\mathbf{1 6}$ & $\mathbf{2 0}$ \\
\hline \multirow{2}{*}{ Control } & & $42.7 \pm 0.2 \mathrm{cB}$ & $42.4 \pm 0.1 \mathrm{cA}$ & $40.9 \pm 2.6 \mathrm{bA}$ & $40.7 \pm 0.1 \mathrm{bB}$ & $42.9 \pm 8.5 \mathrm{cD}$ & $21.6 \pm 2.9 \mathrm{aA}$ \\
& 10 & $39.4 \pm 1.1 \mathrm{bA}$ & $49.7 \pm 4.9 \mathrm{dC}$ & $48.5 \pm 1.5 \mathrm{dC}$ & $43.8 \pm 4.4 \mathrm{cB}$ & $42.0 \pm 0.2 \mathrm{cD}$ & $22.1 \pm 3.0 \mathrm{aA}$ \\
30 & 20 & $40.1 \pm 2.3 \mathrm{cA}$ & $45.7 \pm 3.7 \mathrm{~dB}$ & $45.8 \pm 3.8 \mathrm{~dB}$ & $36.7 \pm 3.0 \mathrm{bA}$ & $34.5 \pm 2.3 \mathrm{bA}$ & $20.9 \pm 2.7 \mathrm{aA}$ \\
& 30 & $42.9 \pm 0.7 \mathrm{cB}$ & $46.6 \pm 4.7 \mathrm{~dB}$ & $48.7 \pm 2.0 \mathrm{dC}$ & $41.0 \pm 2.1 \mathrm{bB}$ & $38.7 \pm 2.4 \mathrm{bC}$ & $23.0 \pm 2.6 \mathrm{aB}$ \\
& 10 & $41.7 \pm 1.2 \mathrm{cB}$ & $43.4 \pm 3.4 \mathrm{dA}$ & $44.2 \pm 2.8 \mathrm{~dB}$ & $33.9 \pm 3.2 \mathrm{bA}$ & $31.8 \pm 2.4 \mathrm{bA}$ & $24.5 \pm 2.1 \mathrm{aB}$ \\
40 & 20 & $42.0 \pm 1.7 \mathrm{cB}$ & $46.9 \pm 5.8 \mathrm{~dB}$ & $49.1 \pm 3.1 \mathrm{dC}$ & $40.3 \pm 1.5 \mathrm{bB}$ & $38.3 \pm 3.8 \mathrm{bC}$ & $24.1 \pm 2.8 \mathrm{aB}$ \\
& 30 & $43.1 \pm 1.7 \mathrm{cC}$ & $46.3 \pm 4.2 \mathrm{~dB}$ & $48.3 \pm 4.1 \mathrm{dC}$ & $40.0 \pm 4.7 \mathrm{bB}$ & $36.6 \pm 1.6 \mathrm{bB}$ & $23.8 \pm 3.5 \mathrm{aB}$ \\
\hline
\end{tabular}

Data expressed as mean \pm standard deviation of three repetitions. In the same row, different lowercase letters indicate statistically significant differences between treatment days $(p<0.05)$. In the same column, different capital letters indicate statistically significant differences between the treatments $(p<0.05)$.

A significant decrease $(p<0.05)$ in the content of ascorbic acid was observed in the treatments at $30 \mathrm{kHz}$ for 10 and $20 \mathrm{~min}$ on day zero (Table 4). A small production of reactive species due to the lower degassing rate than the other treatments allows reactive species formation. In this way, aerobic oxidation could explain the ascorbic acid losses reflected in these two treatments, which agrees with the trend found in several juices and fresh fruit pulps processed by ultrasound [51], as the juice of Physalis peruviana L. (Uchuva) [39] in Passiflora edulis f. flavicarpa (yellow passion fruit) [52]. Ascorbic acid's oxidation can be caused by the addition of oxygen during the opening of the fruit and handling when working the pulp and by the formation of free radicals during the application of ultrasound, which can form reactive species such as $\mathrm{H}, \mathrm{OH}, \mathrm{HO}_{2}, \mathrm{O}$, and $\mathrm{H}_{2} \mathrm{O}_{2}$, and therefore cause its oxidation immediately [51].

On the contrary, there was a significant increase in ascorbic acid content in the treatments, reaching values of up to $49.1 \pm 3.1 \mathrm{mg}$ ascorbic acid/100 $\mathrm{g}$ of pulp on day 8 of storage. The increase might be caused by the fruit's opening that begins to slowly release some organic acids present at the membranous sacs' level as a protection mechanism, 
including ascorbic acid. From day 12, the content began to decrease, presenting the lowest values on day 20 of storage. In general, the $30 \mathrm{kHz}$ treatments for $30 \mathrm{~min}$ and all the $40 \mathrm{kHz}$ treatments showed the highest ascorbic acid values at the end of the storage period, which suggests that degassing is essential to prevent the oxidation of the pulp components.

\subsection{Color Measurements}

Color is one of the essential appearance attributes in the pulp market, as it is the first quality parameter evaluated by consumers and is critical in the acceptability of the product [53].

The gulupa pulp is not uniform in its appearance and presents two color patterns, a dark color contributed by the seed and its yellow color of the aril. Due to this, the parameters presented significant variability throughout the experiment. Table 5 shows the analysis of the pulp $\mathrm{L}^{*}, \mathrm{a}^{*}$, and $\mathrm{b}^{*}$ coordinates. A significant increase in the $\mathrm{L}^{*}, \mathrm{a}^{*}$, and $b^{*}$ parameters was found with application of ultrasound treatments. The increase in luminosity $\left(\mathrm{L}^{*}\right)$ may result from the decrease in particle size that increases light reflection and increases its luminosity [54] and carotenoid destruction. Similar results were reported by Gómez-López [52] in the juice of Passiflora edulis f. flavicarpa (yellow passion fruit). This increase in $L^{*}$ value can also be attributed to the partial precipitation of unstable particles in the juice, as observed in orange juices subjected to pasteurization processes [55] and orange juice treated by high-intensity pulsed electric fields caused by the increase in temperature [56], which also occurs during prolonged storage as observed in the control. In US treatments, the rise in temperature at the microsites may cause the precipitation of unstable compounds.

Table 5. Color analysis of Passiflora edulis f. edulis Sims (gulupa) pulp subjected to low-frequency ultrasound treatments stored at $4{ }^{\circ} \mathrm{C}$.

\begin{tabular}{|c|c|c|c|c|c|c|c|c|}
\hline \multirow{2}{*}{$\begin{array}{c}\text { Power } \\
(\mathrm{kHz})\end{array}$} & \multirow{2}{*}{ Time (min) } & \multirow{2}{*}{$\begin{array}{l}\text { Parameter } \\
\text { Color }\end{array}$} & \multicolumn{6}{|c|}{ Days after Treatment } \\
\hline & & & 0 & 4 & 8 & 12 & 16 & 20 \\
\hline & Control & & $41 \pm 0 \mathrm{aA}$ & $40 \pm 2 \mathrm{aA}$ & $40 \pm 2 \mathrm{aA}$ & $42 \pm 1 \mathrm{aB}$ & $42 \pm 2 \mathrm{aA}$ & $47 \pm 1 b C$ \\
\hline & 10 & & $49 \pm 1 d C$ & $42 \pm 1 \mathrm{bB}$ & $42 \pm 1 b B$ & $39 \pm 1 \mathrm{aA}$ & $44 \pm 2 \mathrm{cB}$ & $42 \pm 2 \mathrm{bA}$ \\
\hline \multirow[t]{3}{*}{30} & 20 & & $42 \pm 1 \mathrm{aA}$ & $42 \pm 2 \mathrm{aB}$ & $42 \pm 0 \mathrm{aB}$ & $44 \pm 1 b C$ & $46 \pm 2 c C$ & $46 \pm 1 \mathrm{cBC}$ \\
\hline & 30 & $L^{*}$ & $46 \pm 2 \mathrm{cB}$ & $39 \pm 1 \mathrm{aA}$ & $39 \pm 1 \mathrm{aA}$ & $41 \pm 1 \mathrm{bB}$ & $42 \pm 1 \mathrm{bA}$ & $45 \pm 1 \mathrm{cB}$ \\
\hline & 10 & & $46 \pm 3 \mathrm{aB}$ & $46 \pm 2 \mathrm{aC}$ & $46 \pm 2 \mathrm{aC}$ & $46 \pm 1 \mathrm{aD}$ & $48 \pm 2 \mathrm{aD}$ & $53 \pm 3 b D$ \\
\hline \multirow[t]{4}{*}{40} & 20 & & $45 \pm 3 c B$ & $40 \pm 1 \mathrm{aA}$ & $42 \pm 1 \mathrm{bB}$ & $46 \pm 1 \mathrm{cD}$ & $46 \pm 1 c C$ & $50 \pm 0 \mathrm{dD}$ \\
\hline & 30 & & $41 \pm 1 \mathrm{aA}$ & $42 \pm 2 \mathrm{aB}$ & $43 \pm 2 \mathrm{abB}$ & $44 \pm 2 b C$ & $44 \pm 2 \mathrm{bB}$ & $45 \pm 3 \mathrm{bB}$ \\
\hline & Control & & $6 \pm 1 \mathrm{aA}$ & $8 \pm 1 \mathrm{cA}$ & $7 \pm 0 \mathrm{bA}$ & $5 \pm 1 \mathrm{aA}$ & $5 \pm 1 \mathrm{aA}$ & $8 \pm 1 c C$ \\
\hline & 10 & & $11 \pm 1 c C$ & $9 \pm 1 b B$ & $8 \pm 1 b B$ & $7 \pm 1 \mathrm{aB}$ & $6 \pm 1 \mathrm{aA}$ & $6 \pm 0 \mathrm{aB}$ \\
\hline \multirow[t]{3}{*}{30} & 20 & & $7 \pm 1 \mathrm{aA}$ & $8 \pm 1 \mathrm{bA}$ & $9 \pm 1 b B$ & $9 \pm 1 b C$ & $6 \pm 1 \mathrm{aA}$ & $7 \pm 1 \mathrm{aB}$ \\
\hline & 30 & $a^{*}$ & $8 \pm 1 b B$ & $8 \pm 0 \mathrm{bA}$ & $8 \pm 1 \mathrm{bB}$ & $7 \pm 1 \mathrm{aB}$ & $6 \pm 1 \mathrm{aA}$ & $7 \pm 1 \mathrm{aB}$ \\
\hline & 10 & & $11 \pm 2 b C$ & $10 \pm 2 \mathrm{bB}$ & $10 \pm 1 b C$ & $8 \pm 2 \mathrm{aB}$ & $6.9 \pm 0.3 \mathrm{aB}$ & $10 \pm 1 b D$ \\
\hline \multirow{4}{*}{40} & 20 & & $9 \pm 2 b B$ & $9 \pm 0 \mathrm{bB}$ & $9 \pm 1 b B$ & $7 \pm 3 \mathrm{abB}$ & $7 \pm 1 \mathrm{abB}$ & $8 \pm 1 b C$ \\
\hline & 30 & & $7 \pm 1 \mathrm{bA}$ & $7 \pm 1 \mathrm{bA}$ & $7 \pm 1 \mathrm{bA}$ & $7 \pm 0 \mathrm{bB}$ & $6 \pm 1 \mathrm{aA}$ & $5 \pm 1 \mathrm{aA}$ \\
\hline & Control & & $20 \pm 1 \mathrm{aA}$ & $23 \pm 2 b B$ & $23 \pm 3 \mathrm{abA}$ & $27 \pm 1 c B$ & $27 \pm 3 c C$ & $28 \pm 1 \mathrm{~dB}$ \\
\hline & 10 & & $32 \pm 2 b D$ & $23 \pm 1 \mathrm{aB}$ & $23 \pm 1 \mathrm{aA}$ & $24 \pm 1 \mathrm{aA}$ & $23 \pm 3 a A B$ & $23 \pm 1 \mathrm{aA}$ \\
\hline \multirow[t]{3}{*}{30} & 20 & & $24 \pm 1 \mathrm{bB}$ & $22 \pm 1 \mathrm{aB}$ & $24 \pm 2 \mathrm{abA}$ & $31 \pm 3 c C$ & $25 \pm 1 b C$ & $26 \pm 3 b B$ \\
\hline & 30 & $b^{*}$ & $28 \pm 2 c C$ & $21 \pm 0 \mathrm{aA}$ & $23 \pm 2 \mathrm{bA}$ & $26 \pm 1 \mathrm{cB}$ & $21 \pm 1 \mathrm{aA}$ & $27 \pm 2 \mathrm{cB}$ \\
\hline & 10 & & $30 \pm 2 \mathrm{dC}$ & $27 \pm 2 b C$ & $28 \pm 2 b B$ & $30 \pm 2 \mathrm{dC}$ & $30 \pm 2 \mathrm{dD}$ & $33 \pm 2 \mathrm{eD}$ \\
\hline \multirow[t]{4}{*}{40} & 20 & & $28 \pm 3 b C$ & $23 \pm 1 \mathrm{aB}$ & $24 \pm 1 \mathrm{aA}$ & $32 \pm 3 b C$ & $23 \pm 1 \mathrm{aB}$ & $30 \pm 1 b C$ \\
\hline & 30 & & $23 \pm 3 b B$ & $20 \pm 1 \mathrm{aA}$ & $22 \pm 1 \mathrm{bA}$ & $23 \pm 1 \mathrm{bA}$ & $23 \pm 2 b B$ & $22 \pm 1 \mathrm{bA}$ \\
\hline & Control & & 0 & $5 \pm 2 \mathrm{aB}$ & $5 \pm 2 \mathrm{aA}$ & $8 \pm 1 \mathrm{bB}$ & $8 \pm 1 b C$ & $11 \pm 1 c B$ \\
\hline & 10 & & $15 \pm 2 c C$ & $5 \pm 1 \mathrm{bB}$ & $5 \pm 1 \mathrm{bA}$ & $5 \pm 1 \mathrm{bA}$ & $5 \pm 3 \mathrm{abB}$ & $3 \pm 1 \mathrm{aA}$ \\
\hline \multirow[t]{3}{*}{30} & 20 & & $5 \pm 2 \mathrm{aA}$ & $4 \pm 1 \mathrm{aB}$ & $7 \pm 1 b B$ & $12 \pm 3 c C$ & $8 \pm 3 b C$ & $8 \pm 3 b B$ \\
\hline & 30 & $\Delta \mathrm{E}^{*}$ & $10 \pm 3 \mathrm{~dB}$ & $3 \pm 1 \mathrm{abA}$ & $4 \pm 1 \mathrm{bA}$ & $7 \pm 1 \mathrm{cB}$ & $2 \pm 1 \mathrm{aA}$ & $9 \pm 2 \mathrm{~dB}$ \\
\hline & 10 & & $13 \pm 5 \mathrm{bBC}$ & $10 \pm 3 \mathrm{abC}$ & $11 \pm 3 b c$ & $12 \pm 3 b C$ & $11 \pm 1 \mathrm{bD}$ & $19 \pm 4 \mathrm{cD}$ \\
\hline \multirow[t]{2}{*}{40} & 20 & & $10 \pm 4 \mathrm{bB}$ & $5 \pm 1 \mathrm{aB}$ & $7 \pm 2 \mathrm{bB}$ & $14 \pm 3 c C$ & $4 \pm 1 \mathrm{aB}$ & $14 \pm 1 c C$ \\
\hline & 30 & & $4 \pm 3 \mathrm{abA}$ & $2 \pm 1 \mathrm{aA}$ & $4 \pm 1 \mathrm{bA}$ & $5 \pm 1 \mathrm{bA}$ & $5 \pm 2 b B$ & $5 \pm 2 \mathrm{bA}$ \\
\hline
\end{tabular}

Data expressed as mean \pm standard deviation of three repetitions. In the same row, different lowercase letters indicate statistically significant differences between treatment days $(p<0.05)$. In the same column, different capital letters indicate statistically significant differences between the treatments $(p<0.05)$. 
The increase in redness $\left(\mathrm{a}^{*}\right)$ and yellowness $\left(\mathrm{b}^{*}\right)$ may be related to the isomerization of carotenoids present in the gulupa pulp [57], which can form compounds with brown color characteristics, similar to those that occur in the browning process. According to Fonteles et al. [11], any change in the values of the parameters $a^{*}$ and $b^{*}$ is associated with a simultaneous change in luminosity value $\left(\mathrm{L}^{*}\right)$ as observed in this experiment, mainly in shelf life. In addition, they increase with the application of ultrasound treatments but decrease with exposure time (day 0 ).

The values found for $\Delta \mathrm{E}^{*}$ (Table 5) showed that all treatments (day 0 ) had significant changes compared to the control and that these changes can be perceptible by the human eye $(\Delta E>2)$ [58]. The smallest global color difference $(\Delta E)$ for the control was found in the $40 \mathrm{kHz}$ treatment at $30 \mathrm{~min}$ through the entire shelf life (day 0 to 20), besides presenting minor variations, possibly related to the lower loss of ascorbic acid in this treatment caused by the rapid elimination of gases dissolved in the pulp.

Most of the treatments with ultrasound showed a $\Delta \mathrm{E}^{*}$ decreasing trend, presenting values lower than the control, especially on day 16 . The trend continued until day 20 except for samples treated at $40 \mathrm{kHz}$ at 10 and $20 \mathrm{~min}$, which remained at values higher than the control. In the untreated pulp (control), there is a tendency to increase the color parameters $\mathrm{L}^{*}, \mathrm{a}^{*}$, and $\mathrm{b}^{*}$, which involves many aspects that can influence the $\Delta \mathrm{E}^{*}$, as was mentioned already. However, these changes can sometimes be desirable because they reinforce its natural color and increase pigment content. In general, sonication treatments can help preserve these pigments [59].

\subsection{Microbiological Analysis}

In the gulupa pulp, no enterobacteria, aerobic mesophilic bacteria, or psychrophilic bacteria were found, neither in the control nor in the samples treated with ultrasound. Gulupa's low $\mathrm{pH}$ ( $\mathrm{pH}$ 2.81) may act as a retardant or growth inhibitor of pathogenic bacteria, which generally require substrates with $\mathrm{pH}$ values higher than 4.6. Acidic foods such as citrus fruits and their products are considered safe for direct consumption because the survival of microorganisms that generally attack food and are pathogenic for humans hardly grow at low pH levels [31]. Additionally, the growth and development of microorganisms such as bacteria require media rich in protein and low in sugar, contrary to those found in gulupa pulp, whose protein content ranges between 0.7 and $0.9 \%$ in the different stages of maturation [5], which may mean that the gulupa is a problematic substrate for the development of bacteria.

A significant decrease in yeast content was observed due to the effect of ultrasound for the $30 \mathrm{kHz}$ treatments at 20 and $30 \mathrm{~min}(1.2-1.3 \log \mathrm{CFU} / \mathrm{mL})$ and all $40 \mathrm{kHz}$ treatments (1.5-2.1 $\log \mathrm{CFU} / \mathrm{mL}$ ) concerning the control (Table 6). This fact is attributed to the ultrasound treatment, where the production of cavitation bubbles in the fluid causes a higher temperature and pressure in the cavitation region, thus achieving the inactivation of the yeasts [32].

Table 6. Yeast count $\left(\log \mathrm{CFU} / \mathrm{mL}\right.$ ) during storage at $4{ }^{\circ} \mathrm{C}$ of Passiflora edulis $\mathrm{f}$. edulis Sims (gulupa) pulp subjected to low-frequency ultrasound treatments.

\begin{tabular}{|c|c|c|c|c|c|c|c|}
\hline \multirow{2}{*}{ Power (kHz) } & \multirow{2}{*}{ Time (min) } & \multicolumn{6}{|c|}{ Day after Treatment } \\
\hline & & 0 & 4 & 8 & 12 & 16 & 20 \\
\hline \multirow{5}{*}{30} & Control & $4.2 \pm 0.2 \mathrm{cD}$ & $3.5 \pm 0.2 \mathrm{bC}$ & $3.2 \pm 0.2 \mathrm{bD}$ & $2.9 \pm 0.2 \mathrm{aC}$ & $2.8 \pm 0.2 \mathrm{a}$ & $2.8 \pm 0.2 \mathrm{a}$ \\
\hline & 10 & $4.2 \pm 0.2 \mathrm{dD}$ & $2.8 \pm 0.2 \mathrm{cB}$ & $2.6 \pm 0.2 b C$ & $2.5 \pm 0.2 \mathrm{bB}$ & $2.0 \pm 0.2 \mathrm{a}$ & n.d \\
\hline & 20 & $3.0 \pm 0.2 \mathrm{cC}$ & $2.7 \pm 0.2 \mathrm{bB}$ & $2.7 \pm 0.2 \mathrm{bC}$ & $2.4 \pm 0.2 \mathrm{aAB}$ & n.d & n.d \\
\hline & 30 & $2.9 \pm 0.2 \mathrm{cC}$ & $2.6 \pm 0.2 \mathrm{bAB}$ & $2.5 \pm 0.2 \mathrm{abC}$ & $2.3 \pm 0.2 \mathrm{aA}$ & n.d & n.d \\
\hline & 10 & $2.7 \pm 0.2 \mathrm{cB}$ & $2.5 \pm 0.1 \mathrm{bA}$ & $2.3 \pm 0.2 \mathrm{aB}$ & $2.2 \pm 0.2 \mathrm{aA}$ & n.d & n.d \\
\hline \multirow[t]{2}{*}{40} & 20 & $2.5 \pm 0.3 \mathrm{cB}$ & $2.4 \pm 0.2 \mathrm{bA}$ & $2.0 \pm 0.2 \mathrm{aA}$ & n.d & n.d & n.d \\
\hline & 30 & $2.1 \pm 0.2 \mathrm{~A}$ & n.d & n.d & n.d & n.d & n.d \\
\hline
\end{tabular}

Data expressed as mean \pm standard deviation of three repetitions. In the same row, different lowercase letters indicate statistically significant differences between treatment days $(p<0.05)$. In the same column, different capital letters indicate statistically significant differences between the treatments $(p<0.05)$. Legend n.d not detected. 
Ultrasound is considered to act on microorganisms' hydrophobic surfaces, which help collision cavitation bubbles and cause severe damage to the cell wall and, consequently, microbial inactivation [60]. However, some authors state that yeast cells are relatively rigid and are not easy to break, due to the cavitation effect, so the inactivation can also be attributed in large part to the formation of free radicals such as hydrogen peroxide and the release of intracellular proteins [61]. Additionally, the initial inactivation could also be favored by the low $\mathrm{pH}$ of the gulupa [9], e.g., bacteria, as indicated by Khandpur and Gogate [62]. Microbe inactivation by ultrasound is sufficient when used combined with other decontamination techniques such as extremes of $\mathrm{pH}$. As occurred in this study, a low $\mathrm{pH}$ of gulupa pulp may increase the antimicrobial efficiency of sonication, possibly attributed to the improved hydroxyl radical production. The results found were higher than those reported by Fan et al. [63] in fresh-cut cucumber, where it was possible to reduce the yeast load by $0.41-0.84 \log$ CFU/g with treatments of $20 \mathrm{kHz}$ for 5 and $15 \mathrm{~min}$. It was also observed that the reduction in yeast colonies increased with the potency and exposure time. According to Adekunte et al. [64] and Bevilacqua et al. [65], potency (as amplitude level) and treatment time are significant in reducing yeast. The lethal effect of ultrasound treatments depends on the type of microorganism due to differences in the composition of their membranes, cell walls, or organelles. [9]. Parameters such as the medium's viscosity, initial microbial load, and processing affect the treatment's susceptibility $[59,66]$. Generally, sonication cavitation is more effective for Gram-negative bacteria and small round cells than for fungi due to the cell surface-to-volume ratio [59].

The shelf-life study results also established that the yeast count through the 20 days of storage at $4{ }^{\circ} \mathrm{C}$ decreased. This decrease in viable yeasts also affected the control treatment, indicating that refrigeration at $4{ }^{\circ} \mathrm{C}$, seen as thermal treatment, helped decrease the yeast load by $2.2 \log \mathrm{CFU} / \mathrm{mL}$ in the 20 days. The further decrease could be because yeasts remain in an acidic environment in the presence of the generated hydroxyl radicals and $\mathrm{H}_{2} \mathrm{O}_{2}$ produced during cavitation, directly attacking yeasts cells. However, the lower yeast load was presented initially because of the ultrasound treatments, which favors the thermal inactivation process. For example, in the treatment with $40 \mathrm{kHz}$ for $30 \mathrm{~min}$, the initial load decreased from 4.2 to $2.1 \log \mathrm{CFU} / \mathrm{mL}$. Thermal inactivation from a lower load was achieved in only four days, while in the control treatment, it decreased (Table 6).

\subsection{Additional remarks}

The use of polypropylene bags for packing the pulp and subsequent ultrasound treatment has advantages because it avoids the subsequent contamination in the packing process. However, ultrasound likely affects the package, causing the release of incorporated or unbound substances. It has been demonstrated that ultrasound, through different mechanisms, including cavitation, can degrade polymers by the reducing molecular weight by breaking the most susceptible chemical bond without changing the chemical nature of the polymer $[67,68]$. Although it occurs in extreme conditions and has been tested only using solvents that facilitate the components' mobility, this degradation can generate a migration to the food [69].

The extension of the technique to more technical industrial processes should evaluate the available ultrasound equipment. Currently, ultrasound applications are based on three methods: Direct application to the product, coupling with the device, and submergence in an ultrasonic bath [8]. The first two techniques offer greater control of the energy delivered to the sample, and they can be used as long as the microbiological safety conditions at the packaging stage allow it. The use of the ultrasound bath is conditioned to migration processes of the packaging toward the food; although there are few studies in this regard, it must be ensured that the migration is below the limits established for implementation. A general aspect in the process is that it is necessary to avoid heating the sample due to the degradation that biomolecules can undergo, which we want to conserve and potentiate; in this sense, refrigeration systems' coupling must be essential in scaling the process. 


\section{Conclusions}

The present study showed that ultrasound treatments increase the TEAC values and ascorbic acid content in the gulupa pulp. In the same way, it was detected that the treatments did not affect other physicochemical properties $(\mathrm{pH}$, soluble solids, titratable acidity). The microbiological analysis determined that the ultrasound treatments induced a significant decrease in the yeast content during the shelf life, especially the treatment with greater frequency and longer exposure time $(40 \mathrm{kHz}, 30 \mathrm{~min})$. The previous finding could become a new way to improve species' safety and quality with similar physicochemical characteristics as it offers a new strategy to enhance and extend the shelf life of chilled gulupa pulp.

Author Contributions: Conceptualization, V.C.-M. and J.D.-O.; methodology, V.C.-M., J.D.-O., C.D.G.-T. and J.S.R.-N.; validation, J.D.-O., M.P.V.-R. and C.C.-L.; formal analysis, V.C.-M., J.D.O., C.D.G.-T. and M.P.V.-R.; investigation, V.C.-M., J.S.R.-N. and E.F.-L.; resources, J.D.-O. and E.F.-L.; data curation, J.D.-O., C.C.-L. and M.P.V.-R.; writing-original draft preparation, V.C.-M. and J.D.-O.; writing-review and editing, C.D.G.-T., M.P.V.-R., C.C.-L. and J.D.-O.; supervision, J.D.-O. and E.F.-L.; project administration, E.F.-L.; funding acquisition, E.F.-L. All authors have read and agreed to the published version of the manuscript.

Funding: This research received no external funding. The authors thank to the Universidad Santiago de Cali for the APC payment.

Institutional Review Board Statement: Not applicable.

Informed Consent Statement: Not applicable.

Data Availability Statement: The data presented in this study are available on request from the corresponding author.

Acknowledgments: The authors thank the SENA Technopark (Center for Technological Development of Technical Assistance to Industry), Astin, and the Association of parceleros Finca San Julián agrarian committee of Bolo Blanco.

Conflicts of Interest: The authors declare no conflict of interest.

\section{References}

1. Ocampo Pérez, J.; Wyckhuys, K. (Eds.) Tecnología Para El Cultivo de la Gulupa (Passiflora Edulis F Edulis Sims) en Colombia, 1st ed.; Centro de Bio-Sistemas de la Universidad Jorge Tadeo Lozano, Centro Internacional de Agricultura-CIAT y Ministerio de Agricultura y Desarrollo Rural: Bogotá, Colombia, 2012; ISBN 978-958-725-092-3.

2. Noreña Triana, M.E. Cadena de Pasifloras. Indicadores e Instrumentos; Ministerio de Agricultura y Desarrollo Rural: Bogotá, Colombia, 2020.

3. Pinzón, I.M.D.P.; Fischer, G.; Corredor, G. Determinación de los estados de madurez del fruto de la gulupa (Passiflora edulis Sims). Agron. Colomb. 2007, 25, 83-95.

4. Dhawan, K.; Dhawan, S.; Sharma, A. Passiflora: A review update. J. Ethnopharmacol. 2004, 94, 1-23. [CrossRef]

5. Jiménez, A.M.; Sierra, C.A.; Rodríguez-Pulido, F.J; González-Miret, M.L.; Heredia, F.J.; Osorio, C. Physicochemical characterisation of gulupa (Passiflora edulis Sims. fo edulis) fruit from Colombia during the ripening. Food Res. Int. 2011, 44, 1912-1918. [CrossRef]

6. Acevedo, M.F.; Harvey, D.R.; Palis, F.G. Food security and the environment: Interdisciplinary research to increase productivity while exercising environmental conservation. Glob. Food Secur. 2018, 16, 127-132. [CrossRef]

7. Alarcon-Rojo, A.D.; Carrillo-Lopez, L.M.; Reyes-Villagrana, R.; Huerta-Jiménez, M.; Garcia-Galicia, I.A. Ultrasound and meat quality: A review. Ultrason. Sonochem. 2019, 55, 369-382. [CrossRef]

8. Chemat, F.; Khan, M.K. Applications of ultrasound in food technology: Processing, preservation and extraction. Ultrason. Sonochem. 2011, 18, 813-835. [CrossRef] [PubMed]

9. Piyasena, P.; Mohareb, E.; McKellar, R.C. Inactivation of microbes using ultrasound: A review. Int. J. Food Microbiol. 2003, 87, 207-216. [CrossRef]

10. Bhavya, M.L.; Hebbar, H.U. Sono-photodynamic inactivation of Escherichia coli and Staphylococcus aureus in orange juice. Ultrason. Sonochem. 2019, 57, 108-115. [CrossRef] [PubMed]

11. Fonteles, T.V.; Costa, M.G.M.; de Jesus, A.L.T.; de Miranda, M.R.A.; Fernandes, F.A.N.; Rodrigues, S. Power ultrasound processing of cantaloupe melon juice: Effects on quality parameters. Food Res. Int. 2012, 48, 41-48. [CrossRef] 
12. Bhargava, N.; Mor, R.S.; Kumar, K.; Sharanagat, V.S. Advances in application of ultrasound in food processing: A review. Ultrason. Sonochem. 2020, 105293. [CrossRef] [PubMed]

13. Kowalski, S.J.; Mierzwa, D.; Stasiak, M. Ultrasound-assisted convective drying of apples at different process conditions. Dry. Technol. 2017, 35, 939-947. [CrossRef]

14. Zhang, L.; Liao, L.; Qiao, Y.; Wang, C.; Shi, D.; An, K.; Hu, J. Effects of ultrahigh pressure and ultrasound pretreatments on properties of strawberry chips prepared by vacuum-freeze drying. Food Chem. 2020, 303, 125386. [CrossRef] [PubMed]

15. Dai, C.; Zhou, X.; Zhang, S.; Zhou, N. Influence of ultrasound-assisted nucleation on freeze-drying of carrots. Dry. Technol. 2016, 34, 1196-1203. [CrossRef]

16. Cheng, X.; Zhang, M.; Xu, B.; Adhikari, B.; Sun, J. The principles of ultrasound and its application in freezing related processes of food materials: A review. Ultrason. Sonochem. 2015, 27, 576-585. [CrossRef] [PubMed]

17. De la Fuente-Blanco, S.; De Sarabia, E.R.-F.; Acosta-Aparicio, V.M.; Blanco-Blanco, A.; Gallego-Juárez, J.A. Food drying process by power ultrasound. Ultrasonics 2006, 44, e523-e527. [CrossRef] [PubMed]

18. Merone, D.; Colucci, D.; Fissore, D.; Sanjuan, N.; Carcel, J.A. Energy and environmental analysis of ultrasound-assisted atmospheric freeze-drying of food. J. Food Eng. 2020, 283, 110031. [CrossRef]

19. Yildiz, G.; Izli, G. The effect of ultrasound pretreatment on quality attributes of freeze-dried quince slices: Physical properties and bioactive compounds. J. Food Process Eng. 2019, 42, e13223. [CrossRef]

20. Rodríguez, Ó.; Eim, V.; Rosselló, C.; Femenia, A.; Cárcel, J.A.; Simal, S. Application of power ultrasound on the convective drying of fruits and vegetables: Effects on quality. J. Sci. Food Agric. 2018, 98, 1660-1673. [CrossRef]

21. Žlabur, J.Š.; Colnar, D.; Voća, S.; Lorenzo, J.M.; Munekata, P.E.S.; Barba, F.J.; Dobričević, N.; Galić, A.; Dujmić, F.; Pliestić, S. Effect of ultrasound pretreatment and drying method on specialized metabolites of honeyberry fruits (Lonicera caerulea var. kamtschatica). Ultrason. Sonochem. 2019, 56, 372-377. [CrossRef]

22. Colucci, D.; Fissore, D.; Rossello, C.; Carcel, J.A. On the effect of ultrasound-assisted atmospheric freeze-drying on the antioxidant properties of eggplant. Food Res. Int. 2018, 106, 580-588. [CrossRef]

23. Ren, F.; Perussello, C.A.; Zhang, Z.; Kerry, J.P.; Tiwari, B.K. Impact of ultrasound and blanching on functional properties of hot-air dried and freeze dried onions. LWT 2018, 87, 102-111. [CrossRef]

24. Soltani Firouz, M.; Farahmandi, A.; Hosseinpour, S. Recent advances in ultrasound application as a novel technique in analysis, processing and quality control of fruits, juices and dairy products industries: A review. Ultrason. Sonochem. 2019, 57, 73-88. [CrossRef]

25. ICONTEC NTC 5468:2012. Jugo (Zumo), Pulpa, Néctar de Frutas y Sus Concentrados; Instituto Colombiano de Normas Técnicas y Certificación: Bogotá, Colombia, 2012; 21p.

26. Wang, J.; Vanga, S.K.; Raghavan, V. High-intensity ultrasound processing of kiwifruit juice: Effects on the ascorbic acid, total phenolics, flavonoids and antioxidant capacity. LWT 2019, 107, 299-307. [CrossRef]

27. Horwitz, W. Official Methods of Analysis of AOAC International, 17th ed.; AOAC International: Gaithersburg, MD, USA, 2000; ISBN 0935584544 .

28. Grande-Tovar, C.D.; Delgado-Ospina, J.; Puerta, L.F.; Rodríguez, G.C.; Sacchetti, G.; Paparella, A.; Chaves-López, C. Bioactive micro-constituents of ackee arilli (Blighia sapida K.D. Koenig). An. Acad. Bras. Cienc. 2019, 91, e20180140. [CrossRef]

29. Villa-Rodríguez, J.A.; Molina-Corral, F.J.; Ayala-Zavala, J.F.; Olivas, G.I.; González-Aguilar, G.A. Effect of maturity stage on the content of fatty acids and antioxidant activity of "Hass" avocado. Food Res. Int. 2011, 44, 1231-1237. [CrossRef]

30. Pertuzatti, P.B.; Sganzerla, M.; Jacques, A.C.; Barcia, M.T.; Zambiazi, R.C. Carotenoids, tocopherols and ascorbic acid content in yellow passion fruit (Passiflora edulis) grown under different cultivation systems. LWT Food Sci. Technol. 2015, 64, 259-263. [CrossRef]

31. Bhat, R.; Kamaruddin, N.S.B.C.; Min-Tze, L.; Karim, A.A. Sonication improves kasturi lime (Citrus microcarpa) juice quality. Ultrason. Sonochem. 2011, 18, 1295-1300. [CrossRef] [PubMed]

32. Abid, M.; Jabbar, S.; Wu, T.; Hashim, M.M.; Hu, B.; Lei, S.; Zhang, X.; Zeng, X. Effect of ultrasound on different quality parameters of apple juice. Ultrason. Sonochem. 2013, 20, 1182-1187. [CrossRef] [PubMed]

33. Franco, G.; Cartagena, J.; Correa, G.; Lobo, M. Physical characterization of gulupa fruits (Passiflora edulis SIMS) during ripening and posthaverst. Rev. Agron. 2013, 21, 48-62.

34. Menéndez Aguirre, O.; Evangelista Lozano, S.; Arenas Ocampo, M.; Bermúdez Torres, K.; Martínez, A.D.V.; Jimenez Aparicio, A. Cambios en la actividad de $\alpha$-Amilasa, pectinmetilesterasa y poligalacturonasa durante la maduración del maracuyá amarillo (passiflora edulis Var. flavicarpa degener). Interciencia 2006, 31, 728-733.

35. Etienne, A.; Génard, M.; Lobit, P.; Mbeguié-A-Mbéguié, D.; Bugaud, C. What controls fleshy fruit acidity? A review of malate and citrate accumulation in fruit cells. J. Exp. Bot. 2013, 64, 1451-1469. [CrossRef] [PubMed]

36. Gani, A.; Baba, W.N.; Ahmad, M.; Shah, U.; Khan, A.A.; Wani, I.A.; Masoodi, F.A.; Gani, A. Effect of ultrasound treatment on physico-chemical, nutraceutical and microbial quality of strawberry. LWT Food Sci. Technol. 2016, 66, 496-502. [CrossRef]

37. Wang, J.; Wang, J.; Ye, J.; Vanga, S.K.; Raghavan, V. Influence of high-intensity ultrasound on bioactive compounds of strawberry juice: Profiles of ascorbic acid, phenolics, antioxidant activity and microstructure. Food Control 2019, 96, 128-136. [CrossRef]

38. Cruz-Cansino, N.D.S.; Reyes-Hernández, I.; Delgado-Olivares, L.; Jaramillo-Bustos, D.P.; Ariza-Ortega, J.A.; Ramírez-Moreno, E. Effect of ultrasound on survival and growth of Escherichia coli in cactus pear juice during storage. Braz. J. Microbiol. 2016, 47, 431-437. [CrossRef] 
39. Ordóñez-Santos, L.E.; Martínez-Girón, J.; Arias-Jaramillo, M.E. Effect of ultrasound treatment on visual color, vitamin C, total phenols, and carotenoids content in Cape gooseberry juice. Food Chem. 2017, 233, 96-100. [CrossRef] [PubMed]

40. Adiamo, O.Q.; Ghafoor, K.; Al-Juhaimi, F.; Babiker, E.E.; Mohamed Ahmed, I.A. Thermosonication process for optimal functional properties in carrot juice containing orange peel and pulp extracts. Food Chem. 2018, 245, 79-88. [CrossRef]

41. Tiwari, B.K.; O'Donnell, C.P.; Cullen, P.J. Effect of sonication on retention of anthocyanins in blackberry juice. J. Food Eng. 2009, 93, 166-171. [CrossRef]

42. Saeeduddin, M.; Abid, M.; Jabbar, S.; Wu, T.; Hashim, M.M.; Awad, F.N.; Hu, B.; Lei, S.; Zeng, X. Quality assessment of pear juice under ultrasound and commercial pasteurization processing conditions. LWT Food Sci. Technol. 2015, 64, 452-458. [CrossRef]

43. Walkling-Ribeiro, M.; Noci, F.; Cronin, D.A.; Lyng, J.G.; Morgan, D.J. Shelf life and sensory evaluation of orange juice after exposure to thermosonication and pulsed electric fields. Food Bioprod. Process. 2009, 87, 102-107. [CrossRef]

44. Franco, G.; Cartagena, V.J.R.; Correa, L.G.; Rojano, B.; Piedrahita, C.A. Antioxidant activity of Passiflora edulis Sims (purple passion fruit) juice in the postharvest period. Rev. Cuba. Plantas Med. 2014, 19, 154-166.

45. Saravanan, S.; Parimelazhagan, T. In vitro antioxidant, antimicrobial and anti-diabetic properties of polyphenols of Passiflora ligularis Juss. fruit pulp. Food Sci. Hum. Wellness 2014, 3, 56-64. [CrossRef]

46. Sasikala, V.; Saravana, S.; Parimelazhagan, T. Evaluation of antioxidant potential of different parts of wild edible plant Passiflora foetida L. J. Appl. Pharm. Sci. 2011, 1, 89-96.

47. Tomadoni, B.; Cassani, L.; Viacava, G.; Moreira, M.D.R.; Ponce, A. Effect of ultrasound and storage time on quality attributes of strawberry juice. J. Food Process Eng. 2017, 40, e12533. [CrossRef]

48. Ramos dos Reis, L.C.; Pesamosca Facco, E.M.; Flôres, S.H.; de Oliveira Rios, A. Stability of functional compounds and antioxidant activity of fresh and pasteurized orange passion fruit (Passiflora caerulea) during cold storage. Food Res. Int. 2018, 106, 481-486. [CrossRef] [PubMed]

49. Piljac-Žegarac, J.; Valek, L.; Martinez, S.; Belščak, A. Fluctuations in the phenolic content and antioxidant capacity of dark fruit juices in refrigerated storage. Food Chem. 2009, 113, 394-400. [CrossRef]

50. Franco, M.N.; Galeano-Díaz, T.; López, Ó.; Fernández-Bolaños, J.G.; Sánchez, J.; De Miguel, C.; Gil, M.V.; Martín-Vertedor, D. Phenolic compounds and antioxidant capacity of virgin olive oil. Food Chem. 2014, 163, 289-298. [CrossRef]

51. Aguilar, K.; Garvín, A.; Ibarz, A.; Augusto, P.E.D. Ascorbic acid stability in fruit juices during thermosonication. Ultrason. Sonochem. 2017, 37, 375-381. [CrossRef]

52. Gómez-López, V.M.; Buitrago, M.E.; Tapia, M.S.; Martínez-Yépez, A. Effect of ultrasonication on microbial quality, colour, and ascorbic acid content of passion-fruit juice during storage. Acta Aliment. 2017, 46, 470-480. [CrossRef]

53. Tanner, D. Impacts of Storage on Food Quality. Ref. Modul. Food Sci. 2016, 1-4. [CrossRef]

54. Valero, M.; Recrosio, N.; Saura, D.; Muñoz, N.; Martí, N.; Lizama, V. Effects of ultrasonic treatments in orange juice processing. J. Food Eng. 2007, 80, 509-516. [CrossRef]

55. Lee, H.S.; Coates, G.A. Effect of thermal pasteurization on Valencia orange juice color and pigments. LWT Food Sci. Technol. 2003, 36, 153-156. [CrossRef]

56. Cortés, C.; Esteve, M.J.; Frígola, A. Color of orange juice treated by High Intensity Pulsed Electric Fields during refrigerated storage and comparison with pasteurized juice. Food Control 2008, 19, 151-158. [CrossRef]

57. Sandi, D.; Paes Chaves, J.B.; Gomes de Sousa, A.C.; Parreiras, J.F.M.; Coelho da Silva, M.T.; Lessa Constant, P.B. Hunter color dimensions, sugar content and volatile compounds in pasteurized yellow passion fruit juice (Passiflora edulis var. flavicarpa) during storage. Braz. Arch. Biol. Technol. 2004, 47, 233-245. [CrossRef]

58. Choi, M.H.; Kim, G.H.; Lee, H.S. Effects of ascorbic acid retention on juice color and pigment stability in blood orange (Citrus sinensis) juice during refrigerated storage. Food Res. Int. 2002, 35, 753-759. [CrossRef]

59. Abdullah, N.; Chin, N.L. Application of Thermosonication Treatment in Processing and Production of High Quality and Safe-to-Drink Fruit Juices. Agric. Agric. Sci. Procedia 2014, 2, 320-327. [CrossRef]

60. Zinoviadou, K.G.; Galanakis, C.M.; Brnčić, M.; Grimi, N.; Boussetta, N.; Mota, M.J.; Saraiva, J.A.; Patras, A.; Tiwari, B.; Barba, F.J. Fruit juice sonication: Implications on food safety and physicochemical and nutritional properties. Food Res. Int. 2015, 77, 743-752. [CrossRef]

61. Režek Jambrak, A.; Šimunek, M.; Evačić, S.; Markov, K.; Smoljanić, G.; Frece, J. Influence of high power ultrasound on selected moulds, yeasts and Alicyclobacillus acidoterrestris in apple, cranberry and blueberry juice and nectar. Ultrasonics 2018, 83, 3-17. [CrossRef]

62. Khandpur, P.; Gogate, P.R. Effect of novel ultrasound based processing on the nutrition quality of different fruit and vegetable juices. Ultrason. Sonochem. 2015, 27, 125-136. [CrossRef] [PubMed]

63. Fan, K.; Zhang, M.; Jiang, F. Ultrasound treatment to modified atmospheric packaged fresh-cut cucumber: Influence on microbial inhibition and storage quality. Ultrason. Sonochem. 2019, 54, 162-170. [CrossRef] [PubMed]

64. Adekunte, A.O.; Tiwari, B.K.; Cullen, P.J.; Scannell, A.G.M.; O'Donnell, C.P. Effect of sonication on colour, ascorbic acid and yeast inactivation in tomato juice. Food Chem. 2010, 122, 500-507. [CrossRef]

65. Bevilacqua, A.; Campaniello, D.; Sinigaglia, M.; Corbo, M.R. Combination of ultrasound and antimicrobial compounds towards Pichia spp. and Wickerhamomyces anomalus in pineapple juice. LWT Food Sci. Technol. 2015, 64, 616-622. [CrossRef]

66. Jalilzadeh, A.; Hesari, J.; Peighambardoust, S.H.; Javidipour, I. The effect of ultrasound treatment on microbial and physicochemical properties of Iranian ultrafiltered feta-type cheese. J. Dairy Sci. 2018, 101, 5809-5820. [CrossRef] [PubMed] 
67. Desai, V.; Shenoy, M.A.; Gogate, P.R. Degradation of polypropylene using ultrasound-induced acoustic cavitation. Chem. Eng. J. 2008, 140, 483-487. [CrossRef]

68. Li, Y.; Li, J.; Guo, S.; Li, H. Mechanochemical degradation kinetics of high-density polyethylene melt and its mechanism in the presence of ultrasonic irradiation. Ultrason. Sonochem. 2005, 12, 183-189. [CrossRef] [PubMed]

69. Pilevar, Z.; Bahrami, A.; Beikzadeh, S.; Hosseini, H.; Jafari, S.M. Migration of styrene monomer from polystyrene packaging materials into foods: Characterization and safety evaluation. Trends Food Sci. Technol. 2019, 91, 248-261. [CrossRef] 